\title{
Public health perspectives on noise and cardiovascular disease
}

\author{
Lynnette-Nathalie Lyzwinski
}

Cambridge University, Cambridge, UK

Email:1nl25@cam.ac.uk

Received 4 December 2013; revised 31 December 2013; accepted 15 January 2014

Copyright (C) 2014 Lynnette-Nathalie Lyzwinski. This is an open access article distributed under the Creative Commons Attribution License, which permits unrestricted use, distribution, and reproduction in any medium, provided the original work is properly cited. In accordance of the Creative Commons Attribution License all Copyrights (C) 2014 are reserved for SCIRP and the owner of the intellectual property Lynnette-Nathalie Lyzwinski. All Copyright (C) 2014 are guarded by law and by SCIRP as a guardian.

\section{ABSTRACT}

Introduction: Emerging research suggests that noise impacts human health beyond simply the auditory system. There have been recent amendments to acceptable noise level thresholds within the occupational setting and new European Union directives for noise in the community from air and road sources. The purpose of this review will be to assess the relationship between noise and cardiovascular disease in different settings. Methods: A literature review was conducted using PubMed on noise and more cardiovascular disease endpoints. All studies published in the English language between 2000 - present were included. Studies on noise annoyance were excluded. Results: There is a strong positive association between occupational noise exposure and cardiovascular outcomes. There is a moderate association with noise in the community setting from road sources and a weak association with aircraft noise. The strength of the association across settings is dependent on the outcome type, interaction with age and sex of subjects, and time of measurement. Road source noise had the strongest association with myocardial infarction, notably in women during night exposures. The association with hypertension and road noise, when stratified by sex, was significant in men during night-time exposures and in pregnant older women. Only nighttime aircraft noise was associated with statistically significant findings in adults. All sources of noise demonstrate a dose response relationship, which peaks at different noise thresholds. Occupational noise exposure had the strongest association with noise $>85$ dB (A) and duration of exposure. Conclusion: There is sufficient evidence to warrant the precautionary public health principle to reduce noise at the population levels for industry workers through stronger leg- islation, regular compliance inspections, and health promotion. Where population wide noise legislation has not yet been enacted, noise exposure reduction at the individual level may be beneficial.

\section{KEYWORDS}

Occupational Noise; Community Noise;

Cardiovascular Disease; Myocardial Infarction; Hypertension

\section{INTRODUCTION}

Over the past several decades, there has been an increasing awareness that exposure to noise impacts human health. The Control of Noise at Work Regulations 2005 established a precedent for stricter regulatory control of occupational noise exposure in the workplace in the United Kingdom [1]. This legislative enactment prohibits exposure to noise above 87 decibels in the occupational setting and requires employers to regularly assess the hearing of employees who are exposed to 80 decibels [1]. Hearing protection is mandated by law for workers who are exposed to noise levels over 85 decibels [1].

In addition to the public health concern of noise exposure in the occupational setting, most of the global population is increasingly exposed to noise within the community environment. The $21^{\text {st }}$ century's global village is demarcated by increased urbanization trends in tandem with more frequent and diverse modes of transportation [2]. According to the EPA, over $40 \%$ of subjects in the United Kingdom are distressed by traffic related noise within their communities [1].

Although noise exposure in the occupational setting is under regulatory control, there are fewer noise control measures in the community. Whilst the Noise and Statu- 
tory Nuisance Act of 1993 and the Anti-Social Behaviour Act of 2003 regulate noise in the community environment, they do not have a clause which regulates levels of traffic-related and air transportation noise [1]. One particular exception pertains to noise emitted from damaged vehicles due to faulty engines under the Road Vehicles Construction and Use Regulations of 1986 and noise generated from horns in the Road Traffic Act 1972 [1]. In recognition of the need to regulate public exposure levels to transportation noise, the EU Environmental Noise Directive requires the State to reduce noise from airplanes and trains which are within its jurisdictional responsibility and all private sources should thereby set similar action plans [1].

Whilst, much public health education has concentrated on the auditory effects of noise, an emerging area of research in the scientific community concerns non-auditory effects of noise.

The prevailing literature suggests that exposure to noise both in the occupational and community setting may be associated with effects on the cardiovascular system. This is significant as cardiovascular disease is the leading cause of mortality worldwide, accounting for $31.2 \%$ of all deaths, according to [3] the WHO Global Burden of Disease report in 2004. Cardiovascular disease is complex and multi-causal [4]. According to [5] Ndrepepa et al., "traditional cardiovascular risk factors account for only half of the observed variance in the incidence of myocardial infarction" [5].

Given that the majority of the populace is exposed to noise levels throughout the day, there is a need for greater public health research and knowledge translation in this area. Thus, the purpose of this paper will be to determine whether noise is associated with cardiovascular disease.

\section{METHODS}

This review consisted of a PubMed search in January 2013 of studies on "noise and cardiovascular disease" which investigated noise from either community sources of transportation or from the occupational setting. There were no restrictions on cardiovascular outcome type or source of noise. Studies published after the year 2000 were given preference, to ensure policy relevance (For details on the search criteria, refer to the appendix).

\section{RESULTS}

\subsection{Descriptive}

\subsubsection{Study Characteristics General}

A total of 18 studies were selected for review summarized in Table 1 [6-23]. Of these, 9 were cross-sectional,
6 were case control, and 4 were cohort studies. Sample size varied from 137 [6] to 27,464 subjects [7]. The age of participants ranged from 8 [8] to 90 years [9]. Four studies included only male subjects, taking part exclusively in the occupational setting [7,10-12]. The geographic locations spanned Europe, North America, and Asia. All studies adjusted for potential confounding variables ranging from 1 [7] to 13 covariates [13]. All studies were population based, with the exception of two studies [14,15] whose selection of cases and controls were from hospitals. Twelve studies investigated noise exposure in the community setting from road and air transportation sources $[6,8,9] 13-,\left(14^{*}\right.$ also occupational), [15-21]. Seven studies were occupational [7,10-12,] 14* also community, [22,23]. Most were undertaken in specialized settings ranging from lumber mills [7], metal manufacturing plants [10], to aircraft manufacturing [11].

\subsubsection{Exposure Assessment}

The majority of community studies [6,8,9,13-21] either measured noise directly using a dosimeter or estimated noise levels based on Geographic Information System data on local noise maps and traffic flow associated with residences within measurable proximity to the source. Occupational studies [7,10-12,14,22,23] either measured noise directly with a dosimeter, used workplace noise standards and duration of work as a proxy for cumulative exposure, or used subject self-report of noise levels, which are less reliable compared to the former.

Noise was measured as a weighted average sound pressure level $\mathrm{dB}(\mathrm{A})$, often expressed as an equivalent sound level over time (LAeq, T). The equivalent sound level time period measured ranged from 7 - 23 hours (Day) and 23 - 7 hours (Night), and overall 24 hour exposure in the community setting, 8 hour work exposure shifts in the occupational setting. In general, the studies investigated the cardiovascular health effects of noise within levels ranging from $<45 \mathrm{~dB}$ (A) (9) to $>95 \mathrm{~dB}$ (A) [7], with the highest noise level exposure occurring in the occupational industry [7]. Additionally, noise level exposures during the night time were lower than during the daytime in the community setting. Studies investigating noise from aircrafts also measured sound by Lmax, the maximum sound pressure level which ranged from $<$ $72 \mathrm{~dB}$ (A) [16] to $116 \mathrm{~dB}$ (A) [6].

\subsubsection{Outcome Assessment}

The outcomes in this review were hypertension in 12 studies [6,8,9,10,12,16-23], changes in mean blood pressure in two studies [11,13], myocardial infarction in three $[7,14,15]$, angina pectoris and CHD in two $[20,21]$. Hypertension was defined as blood pressure $>140 / 90$ mm HG. The outcome was measured directly with a 
Table 1. Study characteristics.

\begin{tabular}{|c|c|c|c|c|c|c|c|c|c|c|}
\hline Study & Location & Age & Sex & $\mathbf{N}$ & Design & Outcome & Measurement & $\begin{array}{l}\text { Noise Levels } \\
\text { dB(A) }\end{array}$ & $\begin{array}{l}\text { Effect OR unless } \\
\text { specified with } \\
95 \% \text { CI }\end{array}$ & $\begin{array}{l}\text { Exposure } \\
\text { Assessment }\end{array}$ \\
\hline \multicolumn{11}{|c|}{ Community studies (Road) only } \\
\hline \multirow[t]{4}{*}{$\begin{array}{l}\text { Weinmann } \\
\text { et al. } \\
\text { (2011) }\end{array}$} & $\begin{array}{l}\text { S. Germany, } \\
\text { Munich, } \\
\text { Freising }\end{array}$ & $8-65$ & $\mathrm{M}$ & 1742 & $\begin{array}{l}\text { Cross- } \\
\text { sectional }\end{array}$ & Hypertension & $\begin{array}{l}\text { Sphygmomanometer, } \\
2 \mathrm{x}, 2 \text { days }\end{array}$ & $\begin{array}{l}\text { Children: day } \\
\text { Mean } 79.6\end{array}$ & $0.93(0.64-1.35)$ & $\begin{array}{l}\text { Dosimeter } \\
\text { (Manual) }\end{array}$ \\
\hline & & & & & & & & $\begin{array}{l}\text { Children: night } \\
\text { Mean } 43.7 \text { dB(A) }\end{array}$ & $0.88(0.62-1.25)$ & \\
\hline & & & & & & & & $\begin{array}{l}\text { Adults: day Mean } \\
\text { 74.3(dBA) }\end{array}$ & $0.94(0.68-1.36)$ & \\
\hline & & & & & & & & $\begin{array}{l}\text { Adults: night } \\
\text { Mean } 43.0\end{array}$ & $1.49(1.04-2.13)$ & \\
\hline $\begin{array}{l}\text { Bluhm et } \\
\text { al. (2007) }\end{array}$ & $\begin{array}{l}\text { Sweden, } \\
\text { Stockholm }\end{array}$ & $19-80$ & $\mathrm{M} / \mathrm{F}$ & 667 & $\begin{array}{l}\text { Cross- } \\
\text { Sectional }\end{array}$ & Hypertension & Self-Report & $\begin{array}{l}\text { LAeq } 24 \text { hr. } \\
<45->65 \text { dB(A) }\end{array}$ & $\begin{array}{l}1.38(1.06-1.80) \\
\text { per } 5 \mathrm{~dB}(\mathrm{~A}) \\
\text { increase }\end{array}$ & $\begin{array}{l}\text { Dosimeter, } \\
\text { Noise } \\
\text { Dispersion } \\
\text { Model }\end{array}$ \\
\hline $\begin{array}{l}\text { Chang et } \\
\text { al. (2011) }\end{array}$ & $\begin{array}{l}\text { Taiwan, } \\
\text { Taichung }\end{array}$ & $\begin{array}{l}\text { Mean } \\
M=36.5 \\
(\mathrm{sd} \\
13.9) \\
\mathrm{F}=35.6 \\
(\mathrm{sd}= \\
12.1)\end{array}$ & $\mathrm{M} / \mathrm{F}$ & 820 & $\begin{array}{l}\text { Case } \\
\text { Control }\end{array}$ & Hypertension & Self-Report & $\begin{array}{l}\text { LAeq } 8 \mathrm{~h} \\
\text { 76dBA->83 dBA } \\
\text { Low exposure }<77 \\
\text { dBA High }>83\end{array}$ & $\begin{array}{l}2.15(1.08-4.26) \\
\text { High to Low } \\
\text { exposure }\end{array}$ & Sound Meter \\
\hline $\begin{array}{l}\text { Bodin et } \\
\text { al. (2009) }\end{array}$ & $\begin{array}{l}\text { Southern, } \\
\text { Sweden }\end{array}$ & $18-80$ & $\mathrm{M} / \mathrm{F}$ & 24,238 & $\begin{array}{l}\text { Cross- } \\
\text { Sectional }\end{array}$ & Hypertension & Self-Report & $\begin{array}{l}\text { LAeq } 24 \text { hr. } \\
60-64 \mathrm{~dB}(\mathrm{~A})\end{array}$ & $\begin{array}{l}60-64 \mathrm{~dB}(\mathrm{~A})= \\
1.27(1.02-1.58)\end{array}$ & GIS \\
\hline & & & & & & & & $>65 \mathrm{~dB}(\mathrm{~A})$ & & \\
\hline \multirow[t]{7}{*}{$\begin{array}{l}\text { Willich et } \\
\text { al. (2006) }\end{array}$} & $\begin{array}{l}\text { Berlin (32 } \\
\text { Hospitals) } \\
\text { Germany }\end{array}$ & $\begin{array}{l}\text { Mean M } \\
=56(\mathrm{SD} \\
=9) \mathrm{F}= \\
58(\mathrm{SD}= \\
9)\end{array}$ & $\mathrm{M} / \mathrm{F}$ & 4115 & $\begin{array}{l}\text { Case } \\
\text { Control }\end{array}$ & $\begin{array}{l}\text { Myocardial } \\
\text { Infarction }\end{array}$ & $\begin{array}{l}\text { Patient records (Hos- } \\
\text { pital Data) }\end{array}$ & $\begin{array}{l}\text { Men Day< } 60 \text { ref } \\
\text { dB(A) } 60-65 \\
d B(A) \\
>70 \mathrm{~dB}(\mathrm{~A})\end{array}$ & $\begin{array}{l}>65 \mathrm{~dB}(\mathrm{~A}) \\
=1.45 \\
(1.04-2.02) \\
<60 \mathrm{~dB}(\mathrm{~A})=1 \\
60-65 \mathrm{~dB}(\mathrm{~A}) \\
=1.43 \\
(1.03-1.99) \\
>70 \mathrm{~dB}(\mathrm{~A}) \\
1.74(1.15-2.62)\end{array}$ & $\begin{array}{l}\text { Berlin Road } \\
\text { Traffic Map }\end{array}$ \\
\hline & & & & & & & & $\begin{array}{l}\text { Females Day<60 } \\
60-65 \mathrm{~dB}(\mathrm{~A})\end{array}$ & $\begin{array}{l}<60 \mathrm{~dB}(\mathrm{~A})=1 \\
60-65 \mathrm{~dB}(\mathrm{~A})= \\
2.12(1.15-4.26)\end{array}$ & \\
\hline & & & & & & & & $\begin{array}{l}\text { Females Day }>70 \\
\text { dB(A) }\end{array}$ & $\begin{array}{l}>70=1.74(1.15- \\
2.62)\end{array}$ & \\
\hline & & & & & & & & $\begin{array}{l}\text { Men Night }<50 \text { ref } \\
50-55 \mathrm{~dB}(\mathrm{~A})\end{array}$ & $\begin{array}{l}<50=1 \\
1.23(0.86-1.76) \\
55-60=1.24 \\
(0.86-1.78) \\
>60=1.54 \\
(1.04-2.28)\end{array}$ & \\
\hline & & & & & & & & $\begin{array}{l}55-60 \mathrm{~dB}(\mathrm{~A}) \\
60>\mathrm{dB}(\mathrm{A}) \mathrm{Fe}- \\
\text { males Night } \\
<50 \text { ref dB(A) } \\
50-55 \mathrm{~dB}(\mathrm{~A})\end{array}$ & $\begin{array}{l}<50=1 \\
50-55=3.58 \\
(1.38-8.89)\end{array}$ & \\
\hline & & & & & & & & $55-60 \mathrm{~dB}(\mathrm{~A})$ & $\begin{array}{l}55-60=2.73 \\
(1.26-7.87)\end{array}$ & \\
\hline & & & & & & & & $>60 \mathrm{~dB}(\mathrm{~A})$ & $\begin{array}{l}>60=2.73(1.09- \\
6.84)\end{array}$ & \\
\hline $\begin{array}{l}\text { Selander } \\
\text { et al. } \\
(2009)\end{array}$ & $\begin{array}{l}\text { Sweden, } \\
\text { Stockholm }\end{array}$ & $45-70$ & $\mathrm{M} / \mathrm{F}$ & 3666 & $\begin{array}{l}\text { Case } \\
\text { Control }\end{array}$ & $\begin{array}{l}\text { Myocardial } \\
\text { Infarction }\end{array}$ & Hospital Data & $>550 \mathrm{~dB}(\mathrm{~A})$ & $1.38(1.11-1.71)$ & GIS \\
\hline
\end{tabular}




\section{Continued}

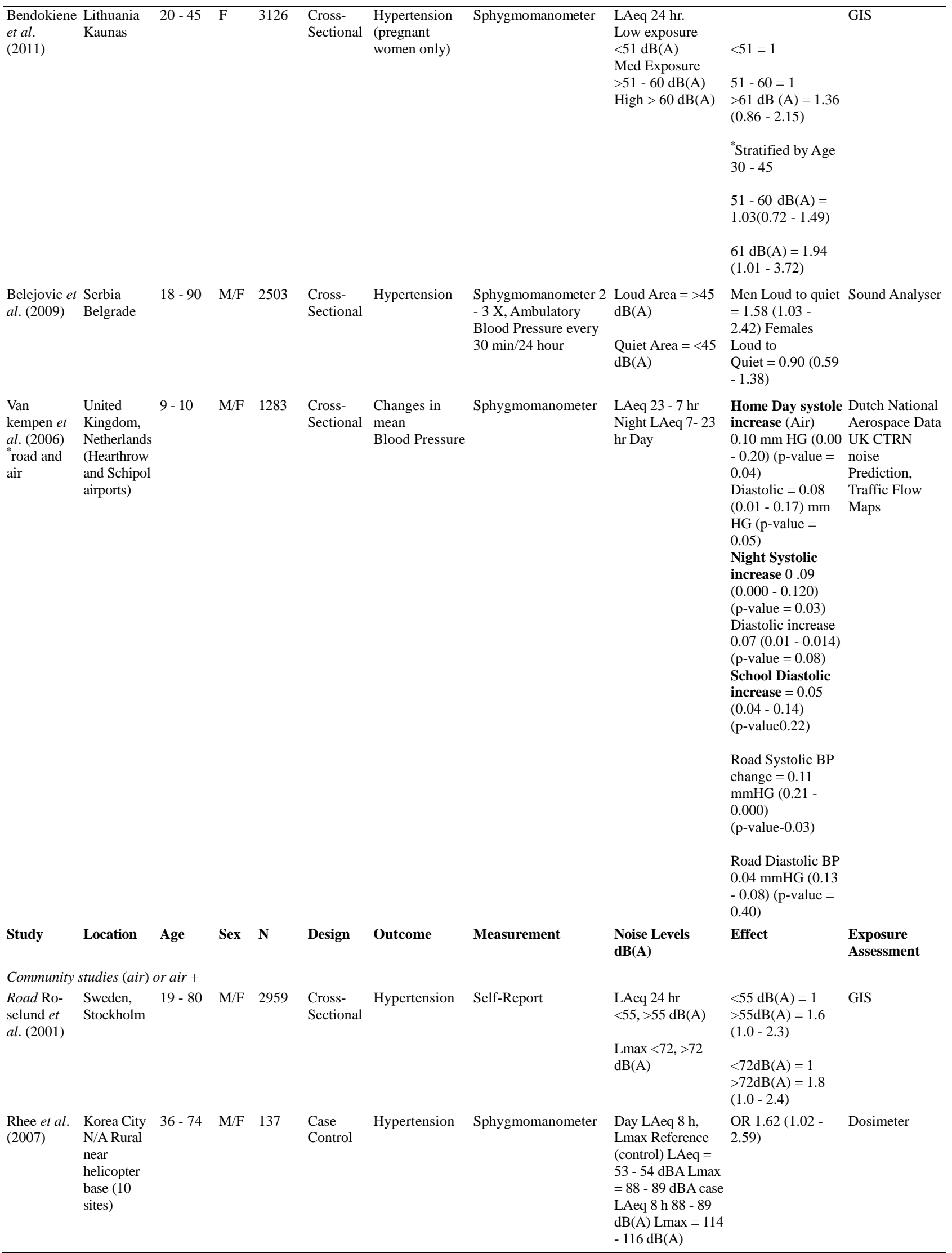




\section{Continued}

\begin{tabular}{|c|c|c|c|c|c|c|c|c|c|c|}
\hline $\begin{array}{l}\text { Jarup et } \\
\text { al. (2008) }\end{array}$ & $\begin{array}{l}\text { EU (6 airports) } \\
\text { London } \\
\text { (Heathrow) } \\
\text { Berlin (Tegel) } \\
\text { Germany, } \\
\text { Amsterdam } \\
\text { (Schiphol) } \\
\text { Netherlands } \\
\text { Stockholm } \\
\text { (Arlanda) } \\
\text { Sweden } \\
\text { Milan } \\
\text { (Malpensa) } \\
\text { Italy, Athens } \\
\text { (Elephterios } \\
\text { Venizelos) } \\
\text { Greece, }\end{array}$ & $45-70$ & $\mathrm{M} / \mathrm{F}$ & 4861 & $\begin{array}{l}\text { Case } \\
\text { Control }\end{array}$ & Hypertension & $\begin{array}{l}\text { Sphygmomanometer } \\
3 \mathrm{x}\end{array}$ & $\begin{array}{l}\text { LAeq, T per } 10 \\
\text { dB(A) increase Air } \\
\text { LAeq, } 16 \mathrm{hr} \\
\text { Air Lnight, } 8 \mathrm{hr} \\
\text { Road LAeq } 24 \mathrm{hr} \\
\text { (range >45 } \\
\text { dB(A)-<75d (BA) }\end{array}$ & $\begin{array}{l}\text { Air } \\
16 \mathrm{hr} \\
\text { LAeq = } 0.928(0.8- \\
1.038) \\
\\
\text { Lnight } \\
\text { Air = 1.141 (1.012 - } \\
1.286) \\
\text { Road } \\
\text { LAeq } \\
24 \mathrm{hr}=1.09(1.003 \\
-1.201)\end{array}$ & GIS \\
\hline \multicolumn{11}{|c|}{ Occupational studies } \\
\hline $\begin{array}{l}\text { Gan et al. } \\
\text { (2011) }\end{array}$ & $\begin{array}{l}\text { Canada (British } \\
\text { Columbia) }\end{array}$ & $>20$ & $\mathrm{M} / \mathrm{F}$ & 6307 & $\begin{array}{l}\text { Cross- } \\
\text { Sectional }\end{array}$ & $\begin{array}{l}\text { Angina } \\
\text { CHD } \\
\text { Hypertension }\end{array}$ & $\begin{array}{l}\text { Self-Report } \\
\text { Biomarkers }\end{array}$ & $\begin{array}{l}\text { Low versus Loud } \\
\text { Noise } \\
\text { dB(A) N/A }\end{array}$ & $\begin{array}{l}\text { Angina }=2.91(1.35 \\
-6.26 \\
\text { CHD }=2.04(1.16- \\
3.58) \\
\text { Hypertension }= \\
2.23(1.21-4.12)\end{array}$ & $\begin{array}{l}\text { Subject } \\
\text { Self-Report }\end{array}$ \\
\hline $\begin{array}{l}\text { Chang et } \\
\text { al. (2013) }\end{array}$ & $\begin{array}{l}\text { Central Taiwan } \\
\text { (Manufacturing } \\
\text { Plant) }\end{array}$ & $\begin{array}{l}\text { Mean } \\
27.6\end{array}$ & M & 578 & $\begin{array}{l}\text { Prospec- } \\
\text { tive } \\
\text { Cohort }\end{array}$ & Hypertension & Sphygmomanometer & $<80->85 \mathrm{~dB}(\mathrm{~A})$ & $\begin{array}{l}\text { RR }>=1.93(95 \% \\
\text { CI: } 1.15-3.22) \\
\text { In > 85 dB(A) } \\
\text { Versus < } 80 \mathrm{~dB}(\mathrm{~A})\end{array}$ & $\begin{array}{l}\text { Weight Sound } \\
\text { Analyser }\end{array}$ \\
\hline $\begin{array}{l}\text { Lee } \text { et al. } \\
\text { (2011) }\end{array}$ & $\begin{array}{l}\text { Korea Busan } \\
\text { Aircraft } \\
\text { manufacturing }\end{array}$ & $\begin{array}{l}16-45 \\
\text { (9 year } \\
\text { follow } \\
\text { up) }\end{array}$ & M & 531 & $\begin{array}{l}\text { Prospectiv } \\
\text { Cohort }\end{array}$ & $\begin{array}{l}\text { Hypertension } \\
\text { (changes in } \\
\text { Mean } \\
\text { BP) }\end{array}$ & Sphygmomanometer & $\begin{array}{l}\text { NLC } \mathbf{I}=<60 \mathrm{~dB}(\mathrm{~A}) \\
\text { ref NLC } \\
\text { II=intermittent } \\
\text { noise }>60 \\
\text { NLCIII = <85 } \\
\text { dB(A) with hear- } \\
\text { ing device } \\
\text { NLCIV=> } 85 \\
\text { dB(A) with ear- } \\
\text { plugs+ muff }\end{array}$ & $\begin{array}{l}\text { Diff in BP 3.8, 2.0, } \\
1.7 \text { mm HG in } \\
\text { NLC-IV,NLC-III, } \\
\text { NLC-II vs. NLC-I }\end{array}$ & Dosimeter \\
\hline $\begin{array}{l}\text { Chang et } \\
\text { al. (2012) }\end{array}$ & $\begin{array}{l}\text { Taiwan Tai- } \\
\text { chung (screw } \\
\text { manufacturing } \\
\text { workers) }\end{array}$ & $28-58$ & M & 202 & $\begin{array}{l}\text { Cross- } \\
\text { Sectional }\end{array}$ & Hypertension & $\begin{array}{l}\text { Sphygmomanometer } \\
2 \mathrm{X}\end{array}$ & $\begin{array}{l}\text { LAeq, } 8 \mathrm{~h} \text { High } \\
\text { exposure }>80 \\
\mathrm{~dB}(\mathrm{~A}) \text { Reference } \\
\text { Low exposure } \\
\text { workers }=75.8+/- \\
3.2 \mathrm{~dB}(\mathrm{~A}) \text { Office } \\
\text { workers } \\
=61.5+/-0.5 \mathrm{~dB}(\mathrm{~A}) \\
\text { Over } 2 \text { - } 4 \text { years, } 4 \\
\text { - } 6,>6 \text { years }\end{array}$ & $\begin{array}{l}>80 \mathrm{~dB}(\mathrm{~A}) 2-4 \\
\text { years }=4.43(1.21- \\
16.5 \text { versus ref } \\
\text { value } 77.6+/-4.4> \\
4-6 \text { years }=1.21 \\
(0.35-4.21)>6 \\
\text { years }=0.95(0.16- \\
5.60)\end{array}$ & $\begin{array}{l}\text { Octave band } \\
\text { Analyser, } \\
\text { Dosimeter, } \\
\text { Sound } \\
\text { Calibrator }\end{array}$ \\
\hline $\begin{array}{l}\text { Gopinath } \\
\text { et al. } \\
\text { (2011) }\end{array}$ & $\begin{array}{l}\text { Australia } \\
\text { Blue Mountain } \\
\text { Cohort }\end{array}$ & $>55$ & $\mathrm{M} / \mathrm{F}$ & 2942 & $\begin{array}{l}\text { Prospectiv } \\
\text { Cohort }\end{array}$ & $\begin{array}{l}\text { Angina } \\
\text { CVD }\end{array}$ & Self-Report & $\begin{array}{l}\text { High versus low } \\
\text { Noise exposure } \\
\text { dB(A) N/A } \\
\text { Over } 1 \text { - } 5 \text { years } \\
\text { >5 years } \\
0 \text { - } 1 \text { year ref }\end{array}$ & $\begin{array}{l}\text { VD } 1 \text { - } 5 \text { years } \\
\text { High } \\
\text { versus low = } 1.27 \\
(0.82-1.96) \\
>5 \text { years } 1.66(1.17 \\
-2.35) \\
\text { Angina } 1 \text { - } 5 \text { years } \\
\text { exposure } 1.54(0.96 \\
-2.49)>5 \text { years } \\
\text { Loud Noise } \\
1.83(1.23 \text { - } 2.71) \\
\text { HR CVD } \\
\text { Mortality } 1 \text { - } 5 \\
\text { years Loud Noise = } \\
1.60(1.10 \text { - } 2.33) \\
\text { HR CVD } \\
\text { Mortality >5 years } \\
\text { Loud } \\
\text { Noise = } 1.10(0.78 \text { - } \\
1.56)\end{array}$ & Self-Report \\
\hline
\end{tabular}




\begin{tabular}{|c|c|c|c|c|c|c|c|c|c|c|}
\hline $\begin{array}{l}\text { Willich et } \\
\text { al. } 2006\end{array}$ & $\begin{array}{l}\text { Germany } \\
\text { Berlin (32 } \\
\text { Hospitals) }\end{array}$ & $\begin{array}{l}M=56 \\
(S D=9) \\
F=58 \\
(S D=9)\end{array}$ & $\mathrm{M} / \mathrm{F}$ & 4115 & $\begin{array}{l}\text { Case } \\
\text { Control }\end{array}$ & $\begin{array}{l}\text { Myocardial } \\
\text { Infarction }\end{array}$ & $\begin{array}{l}\text { Patient Records } \\
\text { (Hospital data) }\end{array}$ & $\begin{array}{l}\text { Work Ref }<55 \text { dBA } \\
55-70 \mathrm{~dB}(\mathrm{~A}),>70 \\
\mathrm{~dB}(\mathrm{~A})\end{array}$ & $\begin{array}{l}\text { OR M dBA<55 = } 1 \\
\text { OR } 55-70 \mathrm{~dB}(\mathrm{~A})= \\
1.19(0.98-1.44)> \\
70 \mathrm{~dB}(\mathrm{~A})=0.92 \\
(0.67-1.21) \\
\mathrm{F}=55=1,55-70 \\
\mathrm{~dB}(\mathrm{~A})=0.88(0.53- \\
1.48), \\
>70 \mathrm{dBA}=0.74 \\
(0.54-1.02)\end{array}$ & $\begin{array}{l}\text { Occupational } \\
\text { Standards } \\
\text { Workplace } \\
\text { Noise }\end{array}$ \\
\hline $\begin{array}{l}\text { Davies et } \\
\text { al. }\end{array}$ & $\begin{array}{l}\text { British } \\
\text { Columbia } \\
\text { (14 Lumber } \\
\text { Mills) }\end{array}$ & $20-36$ & M & 27,464 & $\begin{array}{l}\text { Retrospective } \\
\text { cohort }\end{array}$ & $\begin{array}{l}\text { Myocardial } \\
\text { Infarction } \\
\text { (death) }\end{array}$ & $\begin{array}{l}\text { Canadian Mortality } \\
\text { Database }\end{array}$ & $\begin{array}{l}>85 \mathrm{~dB}(\mathrm{~A}) \text { - Over } 3 \\
\text { - } 20 \text { years } \\
>95 \mathrm{~dB}(\mathrm{~A})\end{array}$ & $\begin{array}{l}\text { RR } 3 \text { years } 85 \\
\text { dB(A) } 1 \\
>85 \mathrm{~dB}(\mathrm{~A}) \\
\text { RR } 10-19 \text { years } \\
=3.9(1.7-8.8) \\
\text { RR > } 19 \text { years } \\
\mathrm{dB}(\mathrm{A})=4.0(1.8- \\
9.3) \\
>95 \text { dBA } \\
\text { RR } 3 \text { years }=1.8 \\
(0.099-3.3) \\
\text { RR } 10-19 \text { years } \\
=1.9(1.1-3.5) \\
\text { RR > } 19 \text { years } \\
=2.7(1.4-4.9)\end{array}$ & $\begin{array}{l}\text { Dosimeter, } \\
\text { Maps, } \\
\text { Cumulative } \\
\text { Exposure }\end{array}$ \\
\hline
\end{tabular}

RR = Relative Risk, OR = Odds Ration, HR = Hazard Ratio, M = males, F = Females, BP = Blood Pressure, GIS = Geographic Information System.

sphygmomanometer on more than one occasion, accounting for observer and intra-individual variability. Subject self-report measures were also used in all outcomes except MI. MI was assessed using hospital patient data.

\subsection{Association with Noise and Cardiovascular Outcomes}

\subsubsection{Air}

Generally, exposure to aircraft noise showed a weak positive association with hypertension, and this was only observed during night-time exposures [8] (OR 1.14, 1.012 - 1.286), with day-time exposures being insignificant (95\% CI include 1) [8]. However, helicopter noise rather than airplane noise, had more significant findings during the day [6] (OR 1.62, 1.02 - 2.59). Additionally, the effect was only significant for systolic and not diastolic blood pressure in children [13]. Higher noise exposure levels also had a stronger association with hypertension, and this was observed in both maximum noise level measurements and time weighted equal energy levels [6, $8,16]$. However, in several of these studies, the $95 \%$ confidence intervals included or were marginally above 1 , indicating that the population null value of no association cannot be completely excluded.

\subsubsection{Road}

Overall, the results from noise in the community setting indicate a moderate positive relationship with cardiovascular outcomes. Living next to a major road had the strongest association with myocardial infarction [14,15]. For instance, male subjects living near a major road were
1.43 times more likely to experience a heart attack relative to subjects living away from a major road (95\% CI 1.03 - 1.99) and females were 2.22 times more likely (1.15 - 4.26) to have an MI for noise levels of 60 - $65 \mathrm{~dB}$ (A) [14].

Additionally, an increasing exposure response relationship was observed at higher noise levels [14,17,19]. For every $5 \mathrm{~dB}(\mathrm{~A})$ increase in noise from the road, the odds of hypertension were 38\% higher (CI 1.06 - 1.80) [17]. The strength of the association was found to increase by dose of noise from $1.27(1.02-1.58)$ at $60-64$ $\mathrm{dB}$ (A) to $1.45(1.04-2.02)$ at $>65 \mathrm{~dB}$ (A) [19]. The dose response differed by sex and tended to reach a plateau after which the effect would decline [14]. For MI, the strength of the association increased in a dose dependent manner from noise levels of $55 \mathrm{~dB}(\mathrm{~A})(\mathrm{OR}=1)$, $60-65(\mathrm{OR}=1.43,1.03-1.99)$, and $>70 \mathrm{~dB}(\mathrm{~A})$ in men (OR1.74, 1.15 - 2.62) but peaked in women at levels of 60 - $65 \mathrm{~dB}$ (A) (OR $2.22,1.15$ - 4.26) and declined thereafter in daytime noise [14]. The effect was stronger during higher night-time exposures [8], notably in women [14]. By contrast, the association with hypertension is only significant in men when stratified by sex (OR 1.58, 1.03 - 2.42) [9], with the exception of the positive interaction in pregnant older women $>30$ years (OR 1.94 $(1.01-3.72)$ at higher noise levels of 61 decibels [20]. It also appears that the association with hypertension pertains to adults, as it was insignificant in children [8].

\subsubsection{Occupational Setting}

Overall, there appears to be a moderate to strong positive association with exposure to workplace noise and cardi- 
ovascular outcomes, particularly in specific industry workers [7,10-12,21]. Only one study had non-significant findings, but concentrated on general workers without focus groups and under lower noise levels of (65 $70,>70 \mathrm{~dB}(\mathrm{~A})$ (14). The general trend is that higher noise exposure levels are associated with an increased risk of one or more CVD endpoints. The occupational studies which concentrated on exposure levels $>80$ - 85 $\mathrm{dB}$ (A) found a stronger exposure response relationship $[7,21]$. For instance, exposure to $>85 \mathrm{~dB}$ (A) relative to the low noise exposure category of $<80 \mathrm{~dB}(\mathrm{~A})$ in manufacturing plant workers is associated with a near two fold increase risk of hypertension $(\mathrm{RR}=1.93$ 95\% CI 1.15 3.22) [21].

Additionally, the strength of the association for MI (death) increases with duration of exposure as subjects exposed to $>85 \mathrm{~dB}$ (A) for 10 - 19 years had relative risks of 3.9 (95\% CI 1.7 - 8.8) and risk continued to increase with over 19 years of exposure, with relative risks of 4.0 (95\% CI 1.8 - 9.3) (7). This indicates that exposed subjects to noise from lumber mills were 3.9 times more likely than non-exposed subjects to die from a myocardial infarction and this risk increased with time [7]. Although the effect also increases with longer exposure duration for hypertension, its maximum effect is reached after 2 - 4 years of exposure at $>80 \mathrm{~dB}$ (A) (OR 4.43, 1.21 - 16.5) and declines thereafter [21].

\section{DISCUSSION}

\subsection{Part A}

\subsubsection{Public Health Assessment}

\section{Application of Sir Bradford Hill's Criteria}

When interpreting the totality of the evidence of an association between noise and cardiovascular outcomes in both the community and occupational setting, there is a need to apply Sir Bradford Hills's 1965 criteria for causation [24].

\section{a) Strength of the association}

The results indicate that there is a moderate to strong association with occupational noise, a moderate association for road sources, and a weak association for air sources.

The strength of the association may be underestimated for occupational noise when workers wore protective gear at exposure levels $>85$ decibels and still had raised systolic blood pressure by $3.8 \mathrm{~mm}$ HG relative to subjects in the lower exposure category NLC I workers exposed to $<60 \mathrm{~dB}$ (A) [11].

\section{b) Dose Response Relationship}

The results indicate that a dose response relationship was found in most studies both in terms of higher noise levels and duration of exposure. However, the relationship is not completely linear, and a threshold effect is reached at different levels across source and outcome types.

\section{c) Temporality}

The cohort studies $[7,11,21]$ in this review established that the antecedent (noise) preceded the consequent (CVD endpoints), a key criterion in Bradford Hill [24].

\section{d) Experiment}

The relationship between noise exposure and cardiovascular disease has not been conducted in human trials but only in animal studies which may provide some insight. The researchers [25] Fisher et al. (1991) found that rats experimentally exposed to air jet noise had a higher systolic blood pressure of $144 \mathrm{~mm} \mathrm{Hg}$ relative to 128 $\mathrm{mm} \mathrm{Hg}$ in non-exposed rats.

\section{e) Consistency across Findings}

The association has been relatively consistent across different types of studies and designs with some variation. The meta-analysis [26] found a pooled effect estimate of 1.14 (95\% CI 1.01 - 1.29) for myocardial infarction in the occupational setting and 1.26 (95\% CI 1.14 1.39) for a myocardial infarction in the community setting. However, their funnel plot indicates some possibility of publication bias whereby negative studies may have been published less [26].

\section{f) Biological Plausibility}

The relationship between noise exposure and cardiovascular disease has been hypothesized to occur through host generated inflammatory reactions.

\subsubsection{Road}

The researchers [27] Babisch et al. (2001) found that subjects who lived near a major road and had bedrooms situated near the road had increased levels of catecholamine in their urine, indicating a neuro-endocrine stress response.

\subsubsection{Air}

Additionally, the HYENA study [28] examining salivary cortisol excretion levels in subjects exposed to aircraft noise across six European countries found an elevation of $6.07 \mathrm{nmol} / \mathrm{L}$ (95\% CI 2.32 - 9.81) in women exposed to aircraft noise above 60 decibels over a 24 hour period but not in men.

\subsubsection{Occupation}

The association between cortisol excretions due to increased noise exposure has also been observed in the Fouladi et al. study [29] whereby subjects exposed to over 80 decibels in the workplace had increased salivary excretion cortisol levels in the evening by $3 \mathrm{nmol} / \mathrm{L}$ relative to levels during leisure days in the evenings (8 $\mathrm{nmol} / \mathrm{L}$ versus $5 \mathrm{nmol} / \mathrm{L}$ ).

1) Coherence with existing knowledge

The ability of host generated inflammation to induce 
cardiovascular disease has been well understood in the scientific community, and the proposed mechanisms by which noise induces cardiovascular effects are in coherence with existing knowledge [30].

\section{2) Confounding}

Covariates controlled for in the studies are summarized in Table 2. The most common covariates controlled for across the studies included socioeconomic status, age, education, employment, smoking, alcohol intake, and BMI. The possibility of confounding cannot be excluded as not all studies controlled for all possible confounding variables. For example, air pollution which is known to have cardiovascular effects is often associated with noise from motor vehicles and aircraft has not been controlled for [31]. Thus, there is a possibility that the association could be explained away by other variables.

\section{3) Bias}

Bias in exposure assessment may occur in case control studies in the form of recall bias. Since cases often recall past exposures than non-cases, the misclassification may likely be differential, leading to bias away from the null [32].

Bias in endpoint assessment may have also occurred in studies where subject self-report of a cardiovascular outcome was used rather than direct measurement. However the authors of several studies argue that misclassification would have been non-differential, leading to bias towards the null as subjects did not link CVD to noise specifically on general questionnaires [17].

\subsection{Part B}

\section{Public Health Protection Measures}

\section{1) The Public Health Precautionary Principle}

Although the association cannot be conclusively determined to be causal without doubt due to weaknesses in observational studies, there is sufficient evidence to warrant adoption of the precautionary principle. This is especially relevant for the occupational setting where

Table 2. Controlled covariates.

1. Chang et al.

age, BMI, male gender, smoking status, alcohol drinking, tea consumption, coffee consumption, daily salt intake, and a family history of hypertension

2. Jarup et al.

Sex, Age, BMI, Country, Alcohol, Smoking, Education, Physical Activity

3. Weinmann et al.

Age, Sex

4. Bluhm et al.

age, smoking, occupational status and house type

5. Roselund et al.

age, sex, smoking, and education

6. Rhee et al.

age, gender, body mass index, current smoking, alcohol intake, diabetes, regular exercise

7. Bodin et al.

age, sex, BMI, alcohol intake, exercise, education, smoking and socioeconomic status.

8. Willich et al.

Diabetes, Hypertension, Smoking, Family History, Obesity, Education, living status (alone), Employment and Hours

9. Selander et al.

Sex , Air Pollution

10. Gopinath et al. (2011)

Smoking, BMI, Blood Pressure (Systolic, Diastolic, Mean),Physical Activity, Mobility Difficulties, Occupation, Self Rated health, Sex, Age, Fat intake, Pre-existing CVD

11. Benzokiene et al. Duration of Residence, Age, Smoking, Alcohol, Education, SES, Marital Status, Pre-existing CVD, Blood Pressure

12. Davies et al. Smoking Status

13. Belejovic et al. Age, SES, Marital Status,Education, Ethnicity, BMI, Pre-existing Conditions, physical Activity

14. Chang et al. 2011 educational level, cigarette smoking, alcohol drinking, tea consumption, coffee consumption, regular exercise, working activity or family history of hypertension

15. Gan et al. Race/Ethnicity, Family Income, Education, Smoking, Alcohol, Physical Activity, Hearing Loss

16. Chang et al. Age, Cholesterol Smoking Status, Education, Profession, Alcohol, Noise Headphones

17. Lee et al. baseline age, smoking, alcohol intake, exercise, family history of hypertension, systolic blood pressure (SBP), or diastolic blood pressure (DBP), and changes in body mass index (BMI)

18. Van Kempen et al. age, gender, ponderosity, school glazing, double glazing at home, employment status, crowding, home ownership, mother's education, ethnicity, cuff size, birth weight, parental high blood pressure, prematurity, and room temperature 
risk estimates were highest. It may also be considered for road sources of noise in the community setting where there was a moderate risk. The principle has been applied throughout the history of public health and officially enshrined for environmental epidemiology in 1998 at the Wingespread Conference [30]. The principle holds that even under instances of uncertainty of causality, public health preventive measures that protect the population should be undertaken if an exposure is a threat to health [30]. Several health protection measures may be used to reduce community and occupational exposure to noise.

\section{2) Population Strategies to reduce exposure}

\section{a) Health Policy}

From the legislative standpoint, there is a need to ensure that all industries with noise exposure in the workplace comply with noise protection guidelines under the Control of Noise at Work 2005 legislation [1]. This may involve more frequent annual inspections of occupational settings in tandem with surveying employees to ensure that they are not exposed to noise above 87 decibels and that they wear noise cancelling devices mandated by the legislation.

Second, there is a need to investigate whether airports and train services have been able to establish guidelines to reduce noise exposure within the community setting. Presently, community members disturbed by transportation noise from these sources may call direct complaint lines to both the airports and train stations and report noise disturbance [1].

\section{b) Health Behavior}

From the behavioral standpoint, individuals exposed to community noise may engage in simple behavioral risk reduction measures. The literature review has demonstrated that noise in the community setting particularly increases blood pressure during the night. Thus, individuals may close bedroom windows, select bedrooms which do not face the street, and wear ear plugs. Families selecting homes may prefer to select areas away from major roads and airports. Less practical noise exposure reduction strategies could involve moving away from a home near a major road, airport, or railway station and selecting residences within quieter neighborhoods.

\section{c) Environmental Health}

From the environmental standpoint, the physical environment may be modified in the home environment to reduce the effects of noise. Triple glazed windows may be installed in tandem with home insulation.

The relationship between exposure to noise, the environment, and the host effects may be demonstrated in the epidemiological paradigm below. Traditionally applied to infectious diseases, it may also be considered in the context of non-communicable diseases [34]. Figure 1

\section{d) Public Health Policy Debate}

A counter argument to the population wide approach which may be taken by some health policy makers is that not all sources of noise confer sufficiently high risks necessitating interventions at the population level. This may pertain to noise from airports, where the risk estimates were weak compared to occupational studies, where population wide regulation appears more feasible.

e) Absolute Risk Approach

The high absolute public health risk approach for vascular disease has been originally described in Law \& Wald [35] whereby individuals at high absolute risk of a multi-causal disease such as cardiovascular disease may benefit from reducing all known risk factors at the individual level. It has been further extended to special high risk population groups in Powles et al. [36] by aggregate methods. They argue high risk groups may benefit from reducing all modifiable vascular risk factors. Under circumstances where population wide noise legislation is not feasible or has not yet been enacted, the high absolute risk approach to public health may be considered. Figure 2 illustrates the multi-causal cardiovascular disease paradigm and demonstrates how these approaches may be applied.

HOST: Worker or Community Resident

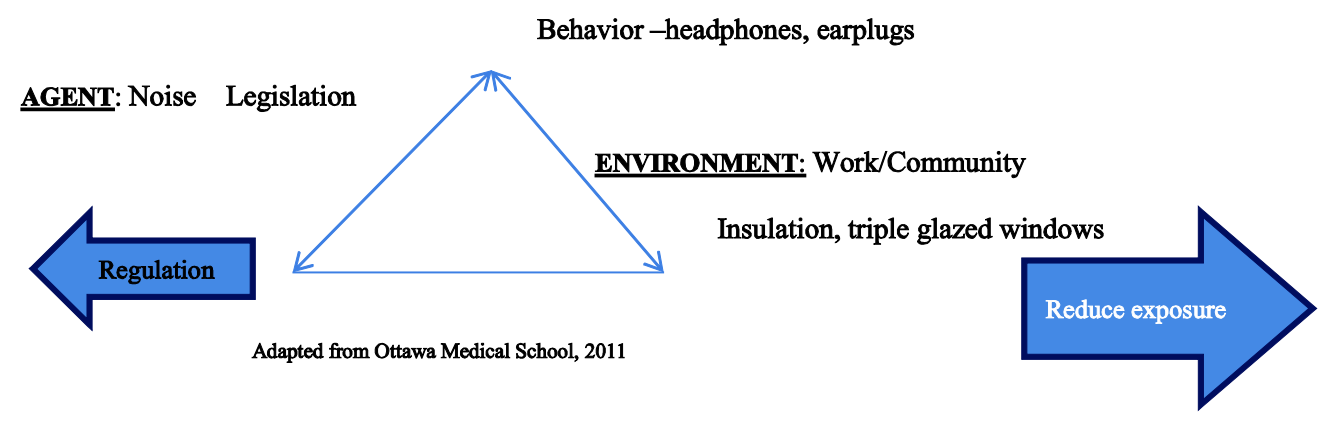

It is through both the integrated effort to regulate the environment and change the host's behavior that the agent (noise) and its subsequent effects on the host in terms of hypertension and myocardial infarction may attenuate

Figure 1. Public health paradigm: Host, agent, environment. 


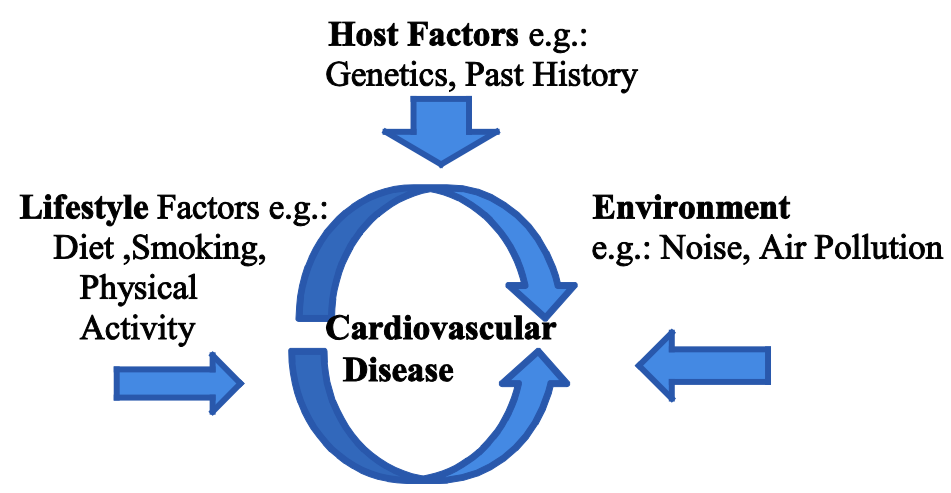

Subjects at high risk of CVD due to Lifestyle, Environment, and Host Factors may engage in behavioural risk reduction and environmental modification such as reduced noise exposure [35-36]

Figure 2. Multi-Causal Cardiovascular Disease Paradigm [31,37].

\section{CONCLUSION}

This paper has argued that there is a moderate-strong positive association between exposure to noise and cardiovascular disease in the workplace and a weak to moderate association in the community setting, generated through host inflammatory mediated reactions. The reviewed studies met several of the Bradford Hill criteria for a possibly causal association. However, due to the described weaknesses and potential biases in observational studies, firm causation could not be concluded. Nonetheless, this paper has adopted the precautionary public health principle for occupational and road noise exposures, as population risks are higher. Public health promotion strategies and greater knowledge translation in local communities and the policy arena could assist with noise exposure reduction at the population level. Simple behavioral, environmental, and legislative enactments may minimize the effects of both occupational and community noise on cardiovascular health at the population level. Individuals at high absolute risk may also engage in behavioral and environmental noise reduction control, without the need for legislation.

\section{REFERENCES}

[1] Environmental Protection UK (2013) Noise pollution. http://www.hpa.org.uk/noise

[2] Nadakuvaren, A. (2005) Our global environment. Waveland Press.

[3] WHO Global Burden of Disease (2004) http://www.who.int/topics/global_burden_of_disease/en/

[4] World Heart Federation (2013) Cardiovascular health. http://www.world-heart-federation.org/

[5] Ndrepepa, A. and Twardella, D. (2011) The relationship between noise annoyance and cardiovascular diseases: A meta-analysis. Noise Health, 13, 251-259. http://dx.doi.org/10.4103/1463-1741.80163

[6] Rhee, M.Y., Kim, H.Y., Roh, S.C., Kim, H.J. and Kwon,
H.J. (2008) The effects of chronic exposure to aircraft noise on the prevalence of hypertension. Hypertension Research, 31. http://dx.doi.org/10.1291/hypres.31.641

[7] Davies, H.W., Teschke, K., Kennedy, S.M., Hodgson, M.R., Hertzman, C. and Demers, P.A. (2005) Occupational exposure to noise and mortality from acute myocardial infarction. Epidemiology, 16, 25-32. http://dx.doi.org/10.1097/01.ede.0000147121.13399.bf

[8] Weinmann, T., Ehrenstein, V., von Kries, R., Nowak, D. and Radon, K. (2012) Subjective and objective personal noise exposure and hypertension: An epidemiologic approach. International Archives of Occupational and Environmental Health, 85, 363-371. http://dx.doi.org/10.1007/s00420-011-0679-7

[9] Belojević, G.A., Jakovljević, B.D., Stojanov, V.J., Slepcević, V.Z. and Paunović, K.Z. (2008) Night-time road traffic noise and arterial hypertension in an urban population. Hyperten Research, 31, 775-781.

[10] Chang, T.Y., Hwang, B.F., Liu, C.S., Chen, R.Y., Wang, V.S., Bao, B.Y. and Lai, J.S. (2013) Occupational noise exposure and incident hypertension in men: A prospective cohort study. American Journal of Epidemiology, 177, 818-825. http://dx.doi.org/10.1093/aje/kws300

[11] Chang, T.Y., Liu, C.S., Young, L.H., Wang, V.S., Jian, S.E. and Bao, B.Y. (2012) Noise frequency components and the prevalence of hypertension in workers. Science of the Total Environment, 416, 89-96. http://dx.doi.org/10.1016/j.scitotenv.2011.11.071

[12] Lee, J.H., Kang, W., Yang, S.R., Choy, N. and Lee, C.R. (2009) Cohort study for the effects of chronic noise exposure on blood pressure in males in Busan Korea. American Journal Indian Medicine, 52, 509-517.

[13] van Kempen, E., van Kamp, I., Fischer, P., Davies, H., Houthuijs, D., Stellato, R., Clark, C. and Stansfeld, S. (2006) Noise exposure and children's blood pressure and heart rate. The RANCH Project, 63, 632-639.

[14] Willich, S., Wegschieder, K., Stallmann, M. and Keil, T. (2006) Noise burden and the risk of myocardial infarction. European Heart Journal, 27, 276-282. http://dx.doi.org/10.1093/eurheartj/ehi658

[15] Selander, J., Nilsson, M.E., Bluhm, G., Roselund, M., Lindquivist, M., Nise, G. and Pershagen, G. (2009) Long-term 
exposure to road traffic noise and myocardial infarction. Epidemiology, 20, 272-279. http://dx.doi.org/10.1097/EDE.0b013e31819463bd

[16] Roselund, M., Berglind, N., Pershagen, G., Jarup, I. and Bluhm, G. (2001) Increased prevalence of hypertension in a population exposed to aircraft noise. Occupational Environmental Medicine, 58, 769-773. http://dx.doi.org/10.1136/oem.58.12.769

[17] Bluhm, L.G., Bergling, N., Nordling, E. and Rosenlund, M. (2007) Road traffic noise and hypertension. Occupational Environmental Medicine, 64, 122-126. http://dx.doi.org/10.1136/oem.2005.025866

[18] Jarup, L., Babisch, W., Houthuijis, D., Pershagen, G., Katsouyanni, K., Cadum, E., Dudley, M.L., Savigny, P., Seiffert, I., et al. (2008) Hypertension and exposure to noise near airports: The HYENA study. Environmental Health Perspectives, 116.

[19] Bodin, T., Albin, M., Ardo, J., Stroh, E. and Ostergren, P. (2009) Road traffic noise and hypertension: Results from a cross-sectional public health survey in southern Sweden. Environmental Health, 8, 38. http://dx.doi.org/10.1186/1476-069X-8-38

[20] Bendokiene, I., Grazuleviciene, R. and Dedele, A. (2011) Risk of hypertension related to road traffic noise among reproductive-age women. Noise Health, 13, 371-377. http://dx.doi.org/10.4103/1463-1741.90288

[21] Chang, T.Y., Liu, C.S., Bao, B.Y., Li, S.E., Chen, T.I. and Lin, Y.J. (2011) Characterization of road traffic noise exposure and prevalence of hypertension in central Taiwan. Science of the Total Environment, 409, 1053-1057. http://dx.doi.org/10.1016/j.scitotenv.2010.11.039

[22] Gopinath, B., Thiagalingam, A., Teber, E. and Mitchell, P. (2011) Exposure to workplace noise and the risk of cardiovascular disease events and mortality in older adults. Preventive Medicine, 53, 390-394. http://dx.doi.org/10.1016/j.ypmed.2011.10.001

[23] Gan, W.Q., Davies, H.W. and Demers, P.A. (2011) Exposure to occupational noise and cardiovascular disease in the United States: The national health and nutrition examination survey 1999-2004. Occupational Environmental Medicine, 68, 183-190. http://dx.doi.org/10.1136/oem.2010.055269

[24] Hill, A.B. (1965) The environment and disease: Association or causation? Proceeding of the Royal Society of Medicine, 58, 295-300.

[25] Fisher, L.D. and Tucker, D.C. (1991) Air jet noise exposure rapidly increases blood pressure in Young Borderline hypertensive rats. Journal of Hypertension, 9, 275-282. http://dx.doi.org/10.1097/00004872-199103000-00012
[26] Van Kempen, E.M.M, Kruize, H., Boshuizen, H.C., Ameling, C.B., Staatsen, B.A.M. and de Hollander, A.E.M. (2002) The association between noise exposure and blood pressure and ischemic heart disease: A meta-analysis. Environmental Health Perspectives, 100.

[27] Babisch, W. (2003) Stress hormones in the research on cardiovascular effects of noise. Noise Health, 5, 1-11.

[28] Fouladi, D.B., Nassiri, P., Monazzam, E.M., Farahani, S., Hassanzadeh, G. and Hoseini, M. (2012) Industrial noise exposure and salivary cortisol in blue collar industrial workers. Noise Health, 14, 184-189.

[29] Selander, J., Bluhm, G., Theorell, T., Pershagen, G., Babisch, W., Seiffert, I., Houthuijs, D., Breugelmans, O., Vigna-Taglianti, F., Antoniotti, M.C., Velonakis, E., Davou, E., Dudley, M.L. and Järup, L. (2009) HYENA consortium. Salivary cortisol and exposure to aircraft noise in Six European cities. Environmental Health Perspectives, 117, 1713-1717.

[30] Pearson, T.A., Mensah, G.A., Alexander, R.W., Anderson, J.L., Cannon, R. III, Criqui,, M., Fadl,, Y.Y., Fortmann, F.P. and Hong, Y. (2003) Markers of inflammation and cardiovascular disease. Circulation, 107, 499-511. http://dx.doi.org/10.1161/01.CIR.0000052939.59093.45

[31] Tonne, C., Melly, S., Mittleman, M., Coull, B., Goldberg, R. and Scwartz, J. (2007) A case control analysis of exposure to traffic and acute myocardial infarction. Environmental Health Perspectives, 115.

[32] Kleinbaum, D.G., Sullivan, K.M. and Barker, N.D. (2007) A pocket guide to epidemiology. Springer, New York.

[33] Science and Environmental Health Network (2013) The precautionary principle.

[34] Ottawa Medical School (2013) Agent host and environmental model of Causation.

http://www.med.uottawa.ca/sim/data/Agent_Host_Enviro nment_e.htm

[35] Law, M.R. and Wald, N.J. (2002) Risk factor thresholds. Their existence under scrutiny. British Medical Journals, 324. http://dx.doi.org/10.1136/bmj.324.7353.1570

[36] Powles, J., Shroufi, A., Mathers, C., Zatonski, W., Vecchia, C.L. and Ezzati, M. (2009) National cardiovascular prevention should be based on absolute disease risks, not levels of risk factors. European Journal of Public Health, 20, 103. http://dx.doi.org/10.1093/eurpub/ckp067

[37] World Heart Federation (2013) Cardiovascular disease risk factors.

http://www.world-heart-federation.org/cardiovascular-he alth/cardiovascular-disease-risk-factors/ 


\section{APPENDIX}

\section{Supplementary Methodology Information}

A literature review using PubMed (Medline) was conducted in early January 2013 investigating the association between noise and one or more cardiovascular disease endpoints. The research question this review sought to answer was whether noise was associated with cardiovascular disease in both the community and occupational setting?

The search terms "noise and cardiovascular disease" were entered into the search engine. The search generated 161 results. Further searchers involved a refinement of the terminology to specific outcomes such as "noise and myocardial infarction" and "stroke" and "angina pectoris". The text terms workplace and community, road, and air were also entered.

Studies whose full reports could not be accessed were manually searched through

Google Scholar to see if they were published in other journals.

The following inclusion and exclusion criteria were applied:

Inclusion Criteria

- All studies on noise and one or more cardiovascular endpoints. No restrictions were placed on outcome type or source type.

- Published in the English language

- Peer Reviewed Journals

- Open Access Journals or accessible through MRC LAB Molecular BIO Cambridge, Library + Athens or NESLI Cambridge University Library

- All Studies published after the year 2000 to ensure policy relevance. Studies may have been conducted earlier than 2000 but must still be relevant and representative of approximate noise levels and relevant to policy change.

\section{Exclusion Criteria}

- Studies which were published before the year 2000 and are no longer relevant to new workplace and community legislation nor representative of current noise levels

- Studies on self-reported noise annoyance, without an indication of how loud the noise was with only annoyance categories given

- Studies examining combined effects of noise and air pollution or noise and stress at work

- Studies in languages other than English

- Studies in journals which were not open access such as: Linpincott Williams \& Wilkins

- Studies whose abstracts were only available 